\title{
ANALYSIS OF FACTORS CONTRIBUTING DELAYS AND CLAIMS IN CONSTRUCTION PROJECTS
}

\author{
Ketki S. Kamble ${ }^{1}$, A. R. Kambekar ${ }^{2}$ \\ ${ }^{1}$ PG. Student, Const. Management, ${ }^{2}$ Assistant Professor, CED, SPCE Andheri (W), Mumbai 400058, Maharashtra, \\ ketki08@gmail.com
}

\begin{abstract}
Construction activities are the most competitive and it involves higher risk with minimum profitability due to competition. Construction of any infrastructural work involves complex management skills related to manpower, materials, plant, machineries, new technologies etc. It also involves many agencies interdependent on each other like the planners, structural and functional designers including various types of specialized engineers and it also includes support of financial institutions, insurers, contractors and specialized contractors. As there are prevailing labour bye laws it needs special care of their well beings. In such kind of complex and intense framework some disputes is quite natural between the agencies involved in such activities which further results in claims management as the unsettled dispute finally leads to financial claims. Higher incidences of disputes are generally reported from the construction contract. Even if there is an appropriate understanding of construction contract clauses from the agencies in the agreement yet claims seems to be a major crisis in the construction sector. The research reported in this paper aims in identifying the major factors responsible of project delay that may give rise to claims for delay damages. The in this paper research mainly highlights on finding the major components of claims with perspective of contractor for delay damages.
\end{abstract}

Keywords: Claims, delay, damages, construction industry, disputes.

\section{INTRODUCTION}

Claims as per Hughes [1] "It is a demand, a request or application for something to which a contractor considers, believes or contends he is entitled but in respect of which agreement has not yet been reached". As per Harris [2] the major five causes of disputes in Asian construction projects are as follows:

- Failure to make interim awards on extensions of time and to give associated compensation

- Unrealistic risk transfer from employers to contractors

- Conflicting party interests

- An unrealistic contract completion date being defined at tender stage

- Incomplete design information or employer requirements.

In general it was reported in literature that the construction sector involves disputes from the sources like changes which includes variation, alteration, addition, deletion, delays and suspensions, differing site conditions, unjust enrichment by owners. It was also observed that there are five potential areas which can give rise to disputes: document errors, estimation errors, change in conditions, implied promises and agencies involved. Claims however fall under two major categories based on their occurrence i.e. during (i) execution of contract and (ii) administration of contract. Execution of contract includes claims due to change in design and drawing, delays in handing over site/issuance of drawings/getting clearance certificate from appropriate authorities, claims due to original scope of work change, claims due to differing site conditions and claims due to variation in methodology. Similarly during administration of contract claims may be due to delay in payment of running account bills and claims due to foreclosure/termination of contract. Similarly delays in schedules of construction projects are one of the most common types of disputes in the construction industry. The client and contractor works for a common objective i.e. to complete the project within scheduled time as well as cost. Time overrun is the most common failure of objective that in turn leads to cost overrun and hence failure in the objective of timely completion leads to failure of overall project budget which ultimately gives rise to disputes. The reasons for delays could be caused by client, contractor, force majeure i.e. act of God, change in laws, rules and regulations, improper coordination between client and contractors, non-availability of required skilled labour, non-availability of required special material, differing site conditions, non-issuance of working drawing and changes in work leading to change in methodology. Delays can be further classified as excusable or non-excusable. Some of the practical cases of non-excusable delays are incompetent sub-contractor, financial incompetency of the contractor, labour disputes hindering work progress, poor workmanship leading to rework, poor material quality and delay in handing over the site by client and excusable 
delay includes sudden floods, natural calamities like earthquake, tsunami etc. riots, labour strike, non-foreseeable situation. Critical delay are defined as a delay in any given activity which results in delay of total project and non-critical delay is defined as delays which may not upset total time frame of the contract [1].

This paper mainly focuses on delay damage claims related to additional cost incurred by the contractor due to delay caused by the client. Evaluation of delay damages are when a contractor bids for a tender, a number of factors are considered apart from the labour, material and equipment that are required to execute the work. In tender the duration required to complete the work is generally mentioned and hence the contractor quotes accordingly. The quote includes material cost, labour cost, plant and machinery cost, shuttering material, human resource cost, financial cost, site overheads and above all profit. In an event of prolongation of contract, the major factors that are affected are additional overheads, plant and machinery, labour and material cost, loss of productivity, loss of profit, loss of new business opportunities and early mobilization.

\section{METHODOLOGY ADOPTED}

Following methodology is adopted for this research work. This includes identification of claims that occur, factors responsible for delay, prolongation claim if any, focus on factors that are affected due to delay in completion the project, factors mostly considered while setting up prolongation claim, ranking based on case studies to understand the major factor affecting the delay damages claim finally recommendations based on the study. The delays which occur in construction projects are due to various reasons. Analysis of three projects have been carried out details of the same is given in Table 1. Project cost, value of claims and claim in $\%$ of project cost for (i) construction of mall in Mumbai, (ii) construction of hotel and casino in Goa and (iii) construction of power transmission tower in Raigad district of Maharashtra is considered in this paper. The range of delay claims by contractor was in the range of around $1.08 \%$ to $400 \%$ of the project cost. This may due to various reasons.

Table1. Analysis of delay damages in construction projects.

\begin{tabular}{|c|l|c|c|c|}
\hline Sr. No & $\begin{array}{c}\text { Project } \\
\text { description }\end{array}$ & $\begin{array}{c}\text { Project } \\
\text { cost } \\
\text { (Lakhs } \\
\text { Rs.) }\end{array}$ & $\begin{array}{c}\text { Value } \\
\text { of claim } \\
\text { (Lakhs } \\
\text { Rs.) }\end{array}$ & $\begin{array}{c}\text { Claim } \\
\text { in \% of } \\
\text { project } \\
\text { cost }\end{array}$ \\
\hline 1 & $\begin{array}{l}\text { Construction } \\
\text { of mall in } \\
\text { Mumbai. }\end{array}$ & 4314 & 623.58 & $14.45 \%$ \\
\hline 2 & $\begin{array}{l}\text { Construction } \\
\text { of hotel and } \\
\text { casino in } \\
\text { Goa. }\end{array}$ & 3494 & 37.68 & $1.08 \%$ \\
\hline
\end{tabular}

\begin{tabular}{|l|l|l|l|l|}
\hline 3 & $\begin{array}{l}\text { Construction } \\
\text { of power } \\
\text { transmission } \\
\text { tower } \\
\text { foundation } \\
\text { in Raigad } \\
\text { district. }\end{array}$ & 12.43 & 49.64 & $400 \%$ \\
\hline
\end{tabular}

\subsection{Project 1: Construction of Mall in Mumbai}

Construction of a mall in Mumbai was taken as first case study for delay claims. The project cost was around 4314 Lakhs Rs., claim amount by contractor was 623.58 Lakhs Rs. and delay was almost of 7 months. Various reasons for claims observed in this case includes the mainly due to delay in approved drawings. The total built up area was around 6,77,000 Sq.ft. and large quantity of MS shuttering material was required to be deployed on site. Since the work was suspended in the middle of project, the resources like staff, machinery was demobilized and transferred to other project, but it was difficult to transfer the shuttering material to other site since the cost of transportation for demobilizing and again mobilizing when the work resumes was observed as a governing factor. Hence in this project $81 \%$ of Claim constitutes for M.S Shuttering Material. Details of claim for various reasons in $\%$ for project 1 are shown in Table 2 . This includes claims for MS shuttering material, labour, overheads and machinery. Next section gives similar analysis for construction of hotel and casino in Goa.

Table2 Details of claim for project 1

\begin{tabular}{|c|l|c|c|c|}
\hline $\begin{array}{c}\text { Sr. } \\
\text { No. }\end{array}$ & Description & $\begin{array}{c}\text { Claim } \\
\text { amount } \\
\text { In Lakhs } \\
\text { Rs.) }\end{array}$ & $\begin{array}{c}\text { Claim } \\
\text { in \% of } \\
\text { project } \\
\text { cost }\end{array}$ & $\begin{array}{c}\text { Importance } \\
\text { as per } \\
\text { claim } \\
\text { amount }\end{array}$ \\
\hline 1 & $\begin{array}{l}\text { M.S. } \\
\text { Shuttering } \\
\text { Material }\end{array}$ & 503.08 & $81 \%$ & 1 \\
\hline 2 & Labour & 58.24 & $9 \%$ & 2 \\
\hline 3 & Overheads & 47.50 & $8 \%$ & 3 \\
\hline 4 & Machinery & 14.75 & $2 \%$ & 4 \\
\hline \multicolumn{2}{|c|}{$\begin{array}{l}\text { Total claim } \\
\text { (In Lakhs Rs.) }\end{array}$} & $\mathbf{6 2 3 . 5 8}$ & \multicolumn{2}{|c|}{} \\
\hline
\end{tabular}

\subsection{Project 2: Construction of Hotel and Casino in}

\section{Goa}

The construction of hotel and casino in Goa was having estimated project cost of 3494 Lakhs Rs. and the claim was 37.68 Lakhs Rs with delay of 1 month. It was noted that the work order given shows the site mobilization within 15 days and in the tender it was also mentioned the minimum staff cadre and equipment needs to be deployed on site at the time of mobilization. Table 3 gives details of claim for various reasons in \% for project 2 showing importance as per claim 
amount. As per the conditions the contractor mobilized the site with the required resources but there was a delay of 1 month in handing over the site. In this case the amount of claim for M.S. shuttering material, overheads and machinery was almost same, since the claim was at the start of the project hence the minimum resources were deployed. The third case study includes the construction of power transmission tower foundation in Raigad district detailed analysis is given in the next section.

Table3. Details of claim for project 2.

\begin{tabular}{|c|l|c|c|c|}
\hline $\begin{array}{c}\text { Sr. } \\
\text { No. }\end{array}$ & Description & $\begin{array}{c}\text { Claim } \\
\text { amount } \\
\text { (In } \\
\text { Lakhs } \\
\text { Rs.) }\end{array}$ & $\begin{array}{c}\text { Claim in } \\
\text { \% of } \\
\text { project } \\
\text { cost }\end{array}$ & $\begin{array}{c}\text { Importance } \\
\text { as per } \\
\text { claim } \\
\text { amount }\end{array}$ \\
\hline $1 \quad \begin{array}{l}\text { M.S } \\
\text { shuttering } \\
\text { material }\end{array}$ & 10.93 & $29 \%$ & 1 \\
\hline 2 & Overheads & 10.60 & $28 \%$ & 2 \\
\hline 3 & Machinery & 9.55 & $25 \%$ & 3 \\
\hline 4 & Labour & 6.60 & $18 \%$ & 4 \\
\hline \multicolumn{2}{|c|}{$\begin{array}{l}\text { Total claim } \\
\text { (In Lakhs Rs.) }\end{array}$} & $\mathbf{3 7 . 6 8}$ & \\
\hline \multicolumn{4}{|l}{} \\
\hline
\end{tabular}

\subsection{Project 3. Construction of Power Transmission}

\section{Tower Foundation in Raigad District}

The scope of work in this case study was to construct RCC power transmission tower foundation at four different locations. Table 4 gives details of claim for project 3. The work was supposed to be executed after getting unhindered land at all the four locations along with the necessary approvals from the local authorities. It was also mentioned that all four locations would be made available at the start of project. The duration of project was 45 days. The contractor mobilized the site with adequate resources but the possession of all the four location was not allotted to the contractor. The working drawing was not issued and the permission from the local authorities was not taken by the client. The total project cost was 12.43 Lakhs Rs., claim amount was 49.64 Lakhs Rs. and the delay resulted the work to be completed in 14.5 months leading to total delay of 13 months. Figure 1 shows details of claims by contractor for project 1,2 and 3 on various elements of the respective projects.

Table4. Details of claim for project 3

\begin{tabular}{|c|l|c|c|c|}
\hline $\begin{array}{c}\text { Sr. } \\
\text { No. }\end{array}$ & Description & $\begin{array}{c}\text { Claim } \\
\text { amount } \\
\text { (In } \\
\text { Lakhs } \\
\text { Rs.) }\end{array}$ & $\begin{array}{c}\text { Claim in } \\
\text { \% of } \\
\text { project } \\
\text { cost }\end{array}$ & $\begin{array}{c}\text { Importance } \\
\text { as per claim } \\
\text { amount }\end{array}$ \\
\hline 1 & Labour & 21.58 & $40 \%$ & 1 \\
\hline 2 & $\begin{array}{l}\text { M.S } \\
\text { Shuttering } \\
\text { Material }\end{array}$ & 10.79 & $20 \%$ & 2 \\
\hline 3 & Overheads & 10.79 & $20 \%$ & 2 \\
\hline 4 & Machinery & 6.47 & $12 \%$ & 3 \\
\hline \multicolumn{2}{|c|}{ Total claim } \\
(In Lakhs Rs.) & $\mathbf{4 9 . 6 4}$ & & \\
\hline
\end{tabular}

Project 1.

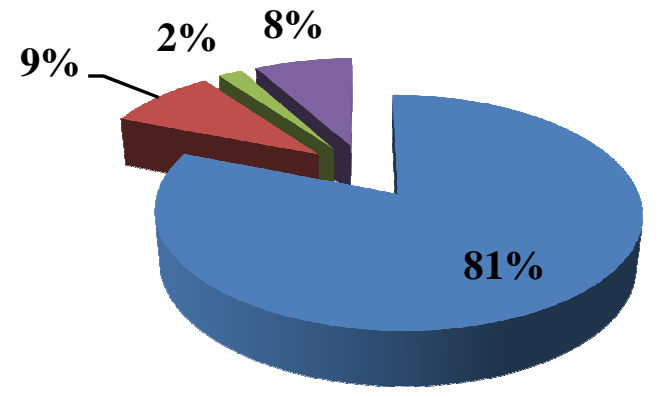

M.S. Shuttering Material

- Labour

Machinery

- Overheads

(a) 


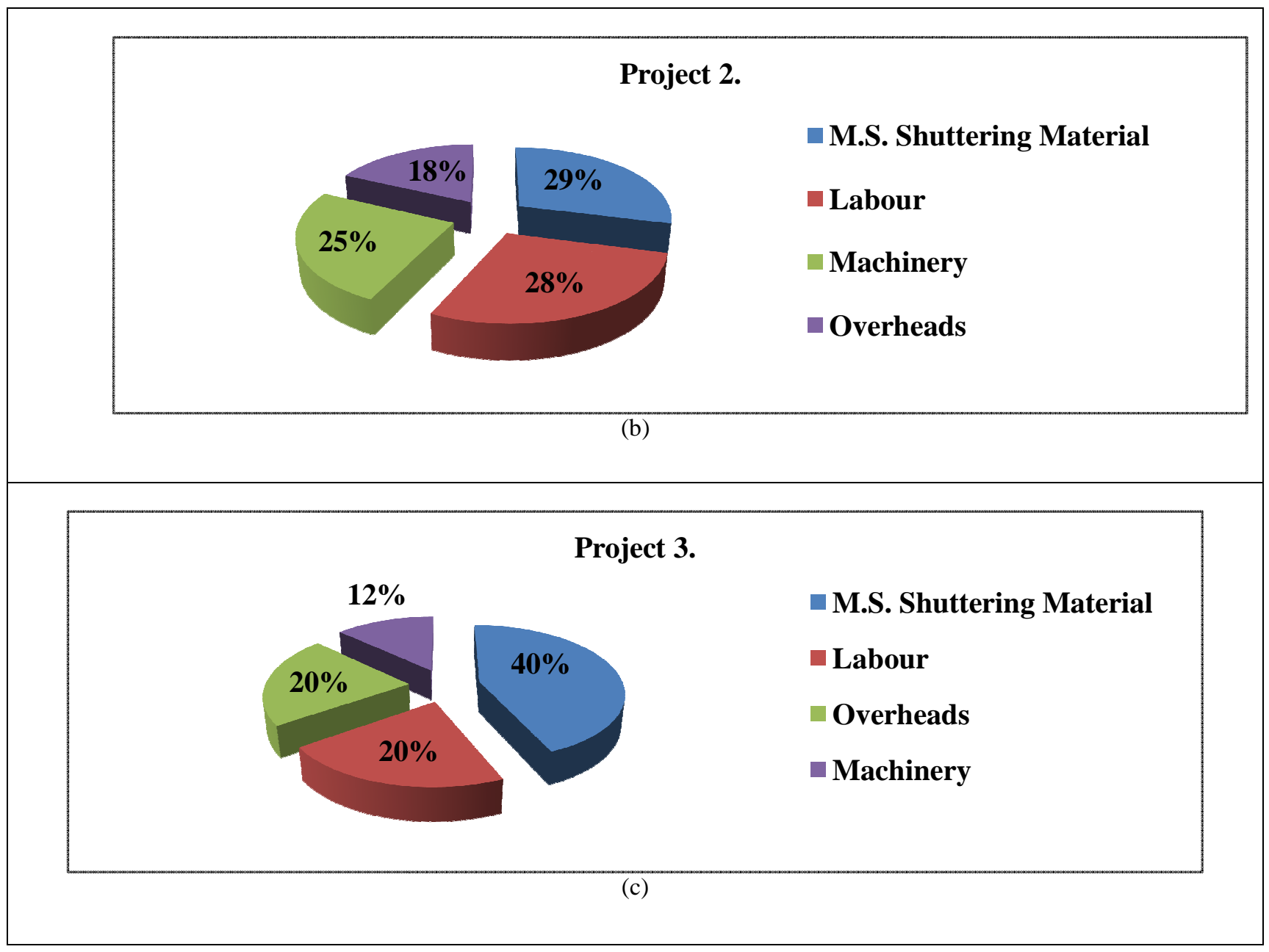

Fig1. Details of claims by contractor for (a) project 1, (b) project 2 and (c) project 3 on various elements

\section{CONCLUSIONS}

The investigation in this work was to identify the major factors responsible for project delay that may give rise to claims for delay damages for three major projects of 1 . Construction of mall, 2. Construction of hotel and casino and 3. Construction of power transmission tower at various locations of India. The main highlights in this study are to find out the major components of claims with perspective of contractor for delay damages. For mall project it can be seen that M.S. shuttering material is most affected factor of delay damages. This is because normally mall constructions are wide spread and the area required for construction is more and hence shuttering required to support the plywood is required in huge quantities. If the project is suspended or delayed the idle charges for the material mounts to a huge expenditure. In case of hotel and casino construction delay in project was mainly due to handing over of site hence all the M.S shuttering material, labour, staff, equipment which were mobilized but underutilized. In this case it was observed that all four factors are equally contributing delay. In case of claims by contractor for power transmission tower foundation project, the delay was due to not handing over of all the four locations unhindered at the same time and delay in drawings. Since the project was supposed to be completed in one and half months, time was the key factor and the contractor mobilized for the complete project but work front was not given. Hence the labour factor was the major affected factor in this case.

\section{RECOMMENDATIONS}

Following are some of the recommendations for clients and contractors of the construction projects

(1) Recommendations for Client: the client should have proper of planning before awarding the work. The design and drawing should be ready before hand to avoid any delay in work. The site should be completely handed over instead of piece meal. Risk analysis of all factors which may lead to delay in work from their end should be taken care of. 
(2) Recommendation for Contractor: It is the duty of the contractor to validate the drawings given by client at the time of bidding the tender. The contractor must also analyze all the factors which may lead to delays from government bodies, changes in rules and regulations. The contractor should also be financially stable to digest the cost overrun leading to delays

\section{REFERENCES}

[1] ED-ON Centre lecture notes: "One day workshop on Contract Administration and Arbitration". Pages 37-43.

[2] E. C. Harris: "Global Construction Disputes 2012: Moving in the Right Direction" Pages 3-5 (2012) 